\title{
Social Media Behaviors of University Students in and out of School: A Field Study
}

\author{
Fatih Çağatay Baz ${ }^{1}$ \\ ${ }^{1}$ Osmaniye Korkut Ata University, Faculty of Economics and Administrative Sciences, Departmant of Management Information Systems, Osmaniye, Turkey, (ORCID: \\ 0000-0002-6398-9851), fatihcagataybaz@osmaniye.edu.tr
}

(First received 13 December 2021 and in final form 23 January 2022)

(DOI: 10.31590/ejosat.1035823)

ATIF/REFERENCE: Baz, F. Ç. (2022). Social Media Behaviors of University Students in and out of School: A Field Study. European Journal of Science and Technology, (33), 126-132.

\begin{abstract}
In recent years, developments in technology and the effects of these developments on human life are quite large. It is seen that future generations will be shaped by rapid advances in technology. Determining the habits of young people, especially in the use of the internet and social media, is important in terms of how the interaction between technology and people should be interpreted. In this research, it is tried to determine the social media behaviors of university students. The aim of the research is to determine the social media behaviors of Osmaniye Korkut Ata University students in and out of school. The questionnaire applied to the students was carried out online in the 2021 fall semester. 170 students participated in the research. The survey consists of three parts. In the first part, there is the demographic information section where the age and gender of the students are included. In the second part, there are questions about the out-of-school social media behaviors of university students. In the third part, there are questions about the inschool social media behaviors of university students. In the analysis part of the data, besides descriptive statistics, t-test for independent samples and one-way analysis of variance were used. In the study, frequency percentage distributions and arithmetic averages of university students participating in the research were calculated with descriptive statistics. In this study, in which the social media behaviors of in-school and out-of-school university students were examined, it was seen that the views of the participants were not significant according to the gender and age variables.
\end{abstract}

Keywords: Social media, Usage of internet, University students, Social media behaviors.

\section{Üniversite Öğrencilerinin Okul İçi ve Dışı Sosyal Medya Davranışları: Bir Alan Araştırması}

$\ddot{O} \mathbf{z}$

Son yıllarda teknolojideki gelişmeler ve bu gelişmelerin insan yaşamına etkileri oldukça fazladır. Gelecek nesillerin teknolojideki hızlı gelişmelerle şekilleneceği görülmektedir. Gençlerin özellikle internet ve sosyal medya kullanım alışkanlıklarının belirlenmesi, teknoloji ve insan etkileşiminin nasıl yorumlanması gerektiği açısından önemlidir. Bu araştırmada üniversite öğrencilerinin sosyal medya davranışları belirlenmeye çalışılmıştır. Araştırmanın amacı, Osmaniye Korkut Ata Üniversitesi öğrencilerinin okul içi ve okul dışı sosyal medya davranışlarını belirlemektir. Öğrencilere uygulanan anket 2021 güz döneminde online olarak gerçekleştirilmiş̧tir. Araştırmaya 170 öğrenci katılmıştır. Anket üç bölümden oluşmaktadır. Birinci bölümde öğrencilerin yaş ve cinsiyetlerinin yer aldığı demografik bilgiler bölümü yer almaktadır. İkinci bölümde ise üniversite öğrencilerinin okul dışı sosyal medya davranışlarına yönelik sorular yer almaktadır. Üçüncü bölümde ise üniversite öğrencilerinin okul içi sosyal medya davranışlarına yönelik sorular yer almaktadır. Verilerin analiz kısmında betimsel istatistiklerin yanı sıra bağımsız örneklemler için t testi ve tek yönlü varyans analizi kullanılmıştır. Araştırmada, araştırmaya katılan üniversite öğrencilerinin frekans yüzde dağılımları ve aritmetik ortalamaları betimsel istatistiklerle hesaplanmıştır. Okul içi ve okul dışı üniversite öğrencilerinin sosyal medya davranışlarının incelendiği bu çalışmada, katılımcıların görüşlerinin cinsiyet ve yaş değişkenlerine göre anlamlı olmadığı görülmüştür.

Anahtar Kelimeler: Sosyal medya, İnternet kullanımı, Üniversite öğrencileri, Sosyal medya davranışları. 


\section{Introduction}

With the rapid development of information technologies, the internet has become an indispensable part of life in recent years. In particular, the use of social media has become quite widespread. People of all age groups are on social media platforms for hours every day. These developments shape people's sharing, communication, and many different issues. Especially young people carry out many activities on the internet and social media platforms.

People do not only use the internet to do some transactions that will make their daily work easier. At the same time, they started to use it for more fun and having a good time. Moreover, at the point we have reached, serious time has begun to be spent on social media (Ince and Koçak 2017). As a reflection of the developing technology, social media is a current issue. Social media is one of the most popular applications of the internet, which is rapidly advancing to become one of the communication tools. Today, the Internet has become not only a place to access information, but also a place that connects individuals and facilitates their socialization. With social media platforms, people want to expand their social circle, communicate with other people, gain knowledge, share knowledge, and experience, and spend their spare time (Barutçu and Tomaş 2013; Aydın 2016). Although social media may seem like dialogues between individuals or small groups, the number of people who are interested in shared information or content is increasing rapidly (Öztürk and Talas, 2015).

The number of people using the Internet is increasing day by day. Internet usage frequency data of individuals in Turkey is given in Table 1.

\section{Table 1. Average internet usage frequency of individuals}

\begin{tabular}{l|c|c|c|c|c|c}
\hline & \multicolumn{2}{|c|}{ Total } & \multicolumn{2}{c|}{ Male } & \multicolumn{2}{c}{ Female } \\
\hline & 2020 & 2021 & 2020 & 2021 & 2020 & 2021 \\
\hline $\begin{array}{l}\text { Almost } \\
\text { every day }\end{array}$ & 70.8 & 76.5 & 76.4 & 81.6 & 65.3 & 71.4 \\
\hline $\begin{array}{l}\text { At least } \\
\text { once a } \\
\text { week }\end{array}$ & 5.6 & 4 & 5.7 & 4 & 5.6 & 4 \\
\hline $\begin{array}{l}\text { Less than } \\
\text { once a } \\
\text { week }\end{array}$ & 1.2 & 0.9 & 1.2 & 0.8 & 1.2 & 0.9 \\
\hline
\end{tabular}

TÜIK (2021), https://data.tuik.gov.tr

When Table 1 is examined, the number of people who use the internet almost every day in 2021 has increased in men and women compared to the previous year. The number of those who say they will enter at least once a week and the number of those who say they will enter less than once a week have also decreased. The developments in the speed of accessing the Internet from year-to-year show that individuals access the Internet every day. Social media addiction is a factor that can affect people's daily functions in their lives and can affect people in cognitive, emotional, and spiritual areas (Ozdemir 2019). Social media, food and beverage, literature, music, urbanism and architecture, design, activities for the benefit of the individual and society, environmentalism, etc. brought together people from different subcultures (Uluç and Yarc1, 2017). Recently, with the rapid development and spread of Web 2.0 technologies, the use of technology and especially the relationship between social media and these issues are examined (Thackeray et al. 2008; Komito 2011; Power and Phillips-Wren 2011; SandovalAlmazan and Gil-Garcia 2014; Sfetcu 2017). When the studies on social media use are examined separately, it is found that studies mostly conducted with young people (Greenhow 2011; Yusop and Sumari 2013; Patton et al. 2014; Rice and BarmanAdhikari 2014; Shabir et al. 2014; Keating and Melis 2017; Baz, 2018; Tutgun-Ünal and Deniz, 2020). Young people use the internet outside of school and in school and spend a lot of time on social media in their environment. In this sense, it is important to examine the social media behaviors of young university students out of school and in school in this study. In line with this importance, the behavior of university students was tried to be determined in this study.

\subsection{Assumptions, Hypotheses and Limitations of the Study}

The effect of the social media environment, which has become widespread recently and the number of users rapidly increasing, on the behavior of university students is gaining importance. Therefore, in the study conducted on Osmaniye Korkut Ata University students, it is aimed to reveal the behaviors of university students out of school and in school.

This study seeks answers to the following basic research questions:

- What are the social media behaviors of university students outside of school?

- What is the social media behavior of university students in school?

- Does the social media behavior of university students differ significantly by gender?

- Does the social media behavior of university students show a significant difference according to their age distribution?

The following assumptions are accepted for the study:

- The propositions in the questionnaire on the social media behaviors of Osmaniye Korkut Ata University students outside and inside the school are sufficient to reveal the social media behaviors of the students in question.

- The research method used in the research is suitable for the purpose and subject of the research.

- The participants who answered the questionnaire are sufficient to determine the out-of-school and inschool social media behaviors of Osmaniye Korkut Ata University students.

The limitations of this study, in which the out-of-school and in-school social media behaviors of university students are investigated, are listed as follows.

- The findings obtained in the study reflect the perceptions of the student group, on which the survey was conducted, regarding out-of-school and in-school social media behaviors at the time of the survey.

- The reliability and validity of the collected data is limited by the characteristics of the technique used in data collection. 
- The limitation of the study is that the data were collected only by questionnaire method and qualitative techniques were not used in the study.

\section{Materials and Methods}

This research was designed in accordance with general survey model. General survey models are the name given to the screening arrangements made on a sample or sample with the idea of making a general judgment about the whole universe or a group to be taken from the universe in a universe consisting of many elements (Karasar 2009). This research is a descriptive study that examines the social media behaviors of university students in and out of school in terms of different variables (age, gender). In descriptive studies, variable manipulation and revealing a cause-effect relationship are out of question. Survey studies fall under the group of such studies. Because these studies do not aim to reveal the relationships between the variables and make predictions for the future. Studies in the descriptive research model are generally called the survey model (Başol 2008).

The research universe consists of students studying at Osmaniye Korkut Ata University and using social media during the period of the research. A total of 170 students were included in the study, in which the purposeful sampling technique was used. The data subject to the research was collected from the participants with Google Forms. While determining the sample, the purposive sampling method, which is one of the non-random sampling methods, was preferred. Büyüköztürk (2012) states the purposive sampling method as the selection of information-rich situations in the context of the purpose of the study to conduct in-depth research.

A questionnaire consisting of 33 questions in 3 parts was used to measure the social media behaviors of the participants in and out of school. The first part of the questionnaire consists of demographic questions. In the second part of the questionnaire, the social media behaviors of the participants outside of school were questioned on a 21-item scale prepared in a 5-point Likert type (1=Never, $2=$ Rarely, $3=$ Sometimes, 4=Often, 5=Always). In the third part of the questionnaire, it was tried to learn the social media behaviors of the participants in the school with a 10-item scale prepared in 5-Likert type (1=Never, 2=Rarely, $3=$ Sometimes, 4=Often, 5=Always). The scales used in the second and third sections of the questionnaire were developed by Dikbaş Torun (2019) with the aim of examining the social media use behaviors of university students in Turkey in terms of various variables. Out-of-school social media behaviors scale; It has four factors: consumption, communication, creation and sharing. The scale of social media behaviors in school has three factors: consuming, creating and sharing. The validity and reliability of the scales were calculated by Dikbaş Torun (2019) using Kaiser-Meyer-Olkin, Bartlett's, Exploratory Factor Analysis, Confirmatory Factor Analysis (CFA) and Cronbach's Alpha tests. In the results, it was seen that the factor loadings of all items were good, and the total variance explained for both scales was at a sufficient level (In-school social media behaviors: $67.64 \%$. Out-of-school social media behaviors: $56.71 \%)$. Internal consistency values of both scales were found to be acceptable for all factors. The results obtained by the exploratory factor analyzes with SPSS 22 software were confirmed by the confirmatory factor analyzes with the AMOS 23 software, and a valid and reliable measurement tool was obtained that measures how the social media usage behaviors of university students in Turkey differ while they are inside and outside the school. The data obtained in the research were analyzed using the SPSS 25 program.

In the analysis part of the data, besides descriptive statistics, t-test for independent samples and one-way analysis of variance were used. In the study, frequency percentage distributions and arithmetic averages of university students participating in the research were calculated with descriptive statistics.

\section{Results and Discussion}

The research findings were obtained from the answers given by 170 participants who participated in the research. Within the scope of the research, the scale was sent to the students in electronic form for them to answer. Google Forms was used to prepare the scale in the electronic environment. It was seen that all the questions sent to the participants were answered.

In this part of the research, the findings obtained as a result of the research are included.

The findings and comments about gender, age, in-school, and out-of-school social media behaviors within the scope of the research are given below, respectively.

\subsection{Demographic Information of Participants}

The distribution of the participants by gender is given in Table 2.

Table 2. Distribution results by gender of the participants

\begin{tabular}{c|c|c}
\hline Gender & f & \% \\
\hline Female & 72 & 42,35 \\
\hline Male & 98 & 57,65 \\
\hline
\end{tabular}

Table 2 shows the distribution of the participants by gender. When Table 2 is examined, $98(57.65 \%)$ of the participants are male; It is seen that $72(42.35 \%)$ of them are women. According to Table 2, the number of male participants is more than female participants.

The distribution of the participants by age groups is given in Table 3 .

Table 3. Distribution results of the participants by age groups

\begin{tabular}{c|c|c}
\hline Age Groups & f & \% \\
\hline $18-20$ age & 45 & 26,47 \\
\hline $21-23$ age & 62 & 36,47 \\
\hline $24-26$ age & 33 & 19,41 \\
\hline 27 and above & 30 & 17,65 \\
\hline
\end{tabular}

Table 3 shows the distribution of the participants by age groups. When Table 3 is examined, $62(36.47 \%)$ of the participants are between the ages of $21-23,45(26.47 \%)$ are between the ages of $18-20,33(19.41 \%)$ are between the ages of $24-26$, and 30 of them are between the ages of 24 and 26. It is seen that $(17.65 \%)$ are in the age range of 27 and over. According to Table 3, it is seen that the age distributions are mostly in the 21-23 age range.

Table 4. Frequency percentage distributions and arithmetic averages of students' views on out-of-school social media behaviors 


\begin{tabular}{|c|c|c|c|c|c|c|c|c|c|c|c|}
\hline \multirow[t]{2}{*}{ Suggestion } & \multicolumn{2}{|c|}{ Never } & \multicolumn{2}{|c|}{ Rarely } & \multicolumn{2}{|c|}{ Sometimes } & \multicolumn{2}{|c|}{ Often } & \multicolumn{2}{|c|}{ Always } & \multirow[t]{2}{*}{$\overline{\mathbf{x}}$} \\
\hline & f & $\%$ & f & $\%$ & f & $\%$ & f & $\%$ & f & $\%$ & \\
\hline \multicolumn{12}{|l|}{ Consuming } \\
\hline Do not look at other people's personal information & 33 & 19,4 & 47 & 27 & 54 & 31,8 & 23 & 13,5 & 13 & 7,6 & 2,62 \\
\hline Reading friends' new posts & 10 & 5,9 & 29 & 17,1 & 65 & 38,2 & 48 & 28,2 & 18 & 10,6 & 3,2 \\
\hline Read comments on friend's or someone else's posts & 36 & 21,2 & 52 & 30,6 & 52 & 30,6 & 23 & 13,5 & 7 & 4,1 & 2,48 \\
\hline $\begin{array}{l}\text { Listening to music or watching TV series and } \\
\text { movies }\end{array}$ & 2 & 1,2 & 13 & 7,6 & 47 & 27,6 & 61 & 35,9 & 47 & 27,6 & 3,81 \\
\hline \multicolumn{12}{|l|}{ Communication } \\
\hline Starting online entertainment activities & 45 & 26,5 & 29 & 17,1 & 49 & 28,8 & 33 & 19,4 & 14 & 8,2 & 2,65 \\
\hline Start online interest-based activities & 44 & 25,9 & 28 & 16,5 & 50 & 29,4 & 27 & 15,9 & 21 & 12,4 & 2,72 \\
\hline $\begin{array}{l}\text { Sending an invitation to an online entertainment } \\
\text { event }\end{array}$ & 61 & 35,9 & 29 & 17,1 & 48 & 28,2 & 24 & 14,1 & 8 & 4,7 & 2,34 \\
\hline $\begin{array}{l}\begin{array}{l}\text { Sending an invitation to online interest-based } \\
\text { events }\end{array} \\
\end{array}$ & 61 & 35,9 & 35 & 20,6 & 43 & 25,3 & 22 & 12,9 & 9 & 5,3 & 2,31 \\
\hline $\begin{array}{l}\text { Write a comment under the topics you are } \\
\text { interested in. }\end{array}$ & 41 & 24,1 & 41 & 24,1 & 57 & 33,5 & 17 & 10 & 14 & 8,2 & 2,54 \\
\hline $\begin{array}{l}\text { Interact with members in interest-based discussion } \\
\text { groups }\end{array}$ & 43 & 25,3 & 40 & 23,5 & 45 & 26,5 & 27 & 15,9 & 15 & 8,8 & 2,59 \\
\hline \multicolumn{12}{|l|}{ Creation } \\
\hline $\begin{array}{l}\text { Adding or remixing someone else's work in } \\
\text { ongoing media conversations }\end{array}$ & 80 & 47,1 & 28 & 16,5 & 37 & 21,8 & 17 & 10 & 8 & 4,7 & 2,08 \\
\hline Rearrange the work of others & 95 & 55,9 & 19 & 11,2 & 31 & 18,2 & 16 & 9,4 & 9 & 5,3 & 1,97 \\
\hline Create video, audio or photos & 66 & 38,8 & 27 & 15,9 & 41 & 24,1 & 21 & 12,4 & 15 & 8,8 & 2,36 \\
\hline Making or rearranging computer and video games & 95 & 55,9 & 20 & 11,8 & 30 & 17,6 & 19 & 11,2 & 6 & 3,5 & 1,94 \\
\hline $\begin{array}{l}\text { Creating digital art content in virtual social } \\
\text { worlds }\end{array}$ & 91 & 53,5 & 27 & 15,9 & 24 & 14,1 & 15 & 8,8 & 13 & 7,6 & 2,01 \\
\hline $\begin{array}{l}\text { Writing on topics of personal interest or } \\
\text { experience }\end{array}$ & 58 & 34,1 & 35 & 20,6 & 38 & 22,4 & 26 & 15,3 & 13 & 7,6 & 2,41 \\
\hline \multicolumn{12}{|l|}{ Sharing } \\
\hline Re-sharing friends' posts on social networks & 53 & 31,2 & 41 & 24,1 & 44 & 25,9 & 18 & 10,6 & 14 & 8,2 & 2,4 \\
\hline Passing fun information & 19 & 11,2 & 24 & 14,1 & 59 & 34,7 & 49 & 28,8 & 19 & 11,2 & 3,14 \\
\hline Forwarding general introduction information & 61 & 35,9 & 38 & 22,4 & 42 & 24,7 & 20 & 11,8 & 9 & 5,3 & 2,28 \\
\hline Sharing the content of topics in my own interests & 38 & 22,4 & 40 & 23,5 & 54 & 31,8 & 22 & 12,9 & 16 & 9,4 & 2,63 \\
\hline $\begin{array}{l}\text { Sharing links or videos from information sharing } \\
\text { groups or groups with common interests }\end{array}$ & 50 & 29,4 & 34 & 20 & 56 & 32,9 & 23 & 13,5 & 7 & 4,1 & 2,42 \\
\hline
\end{tabular}

When Table 4 is examined, it is seen that the participants mostly perform the behaviors of listening to music or watching TV series and movies $(\bar{x}=3.81)$ outside of school. In out-ofschool social media behaviors, it is also seen that the participants display the behaviors of reading the new posts of their friends $(\overline{\mathrm{x}}$ $=3.2$ ) and conveying entertaining information $(\overline{\mathrm{x}}=3.14)$. While the participants had the least behavior of making or rearranging computer and video games $(\overline{\mathrm{x}}=1.94)$, they also had the behavior of rearranging the work of others $(\overline{\mathrm{x}}=1.97)$ and creating digital art content in virtual social worlds $(\overline{\mathrm{x}}=2.01)$ stated that they performed less than others. In the sub-headings of out-of-school social media behaviors, participants list consuming behaviors $(\overline{\mathrm{x}}$ $=3.02)$, sharing behaviors $(\overline{\mathrm{x}}=2.57)$, communication behaviors $(\overline{\mathrm{x}}=2.52)$ and creating behaviors $(\overline{\mathrm{x}}=2.12)$.

The distribution of the participants' views on social media behaviors in school is given in Table 5 . 


\begin{tabular}{|c|c|c|c|c|c|c|c|c|c|c|c|}
\hline \multirow[t]{2}{*}{ Suggestion } & \multicolumn{2}{|c|}{ Never } & \multicolumn{2}{|c|}{ Rarely } & \multicolumn{2}{|c|}{ Sometimes } & \multicolumn{2}{|c|}{ Often } & \multicolumn{2}{|c|}{ Always } & \multirow[t]{2}{*}{$\overline{\mathbf{x}}$} \\
\hline & $\mathbf{f}$ & $\%$ & $\mathbf{f}$ & $\%$ & f & $\%$ & $\mathbf{f}$ & $\%$ & $\mathbf{f}$ & $\%$ & \\
\hline \multicolumn{12}{|l|}{ Consuming } \\
\hline Reading posts about school work on social networks & 12 & 4,8 & 31 & 12,5 & 62 & 25 & 38 & 15,3 & 27 & 10,9 & 3,21 \\
\hline $\begin{array}{l}\text { Searching for learning resources and information } \\
\text { about schoolwork }\end{array}$ & 13 & 5,2 & 31 & 12,5 & 57 & 23 & 43 & 17,3 & 26 & 10,5 & 3,22 \\
\hline $\begin{array}{l}\text { Watching videos about subject knowledge } \\
\text { Creation }\end{array}$ & \multicolumn{8}{|c|}{ Creation } & & 14,5 & 3,58 \\
\hline Writing articles/articles & 40 & 16,1 & 38 & 15,3 & 39 & 15,7 & 34 & 13,7 & 19 & 7,7 & 2,72 \\
\hline Create online video, music and photos & 46 & 18,5 & 33 & 13,3 & 51 & 20,6 & 27 & 10,9 & 13 & 5,2 & 2,57 \\
\hline $\begin{array}{l}\text { Making posters, digital art or graphics } \\
\text { Sharing }\end{array}$ & \multicolumn{10}{|c|}{ Sharing } & 2,23 \\
\hline Discuss school work with classmates or teachers & 33 & 13,3 & 35 & 14,1 & 56 & 22,6 & 31 & 12,5 & 15 & 6 & 2,76 \\
\hline $\begin{array}{l}\text { Sharing information about school issues with } \\
\text { classmates }\end{array}$ & 16 & 6,5 & 27 & 10,9 & 54 & 21,8 & 40 & 16,1 & 33 & 13,3 & 3,27 \\
\hline Sharing learning resources with classmates & 9 & 3,6 & 22 & 8,9 & 61 & 24,6 & 47 & 19,0 & 31 & 12,5 & 3,4 \\
\hline $\begin{array}{l}\text { Sharing extracurricular learning resources with } \\
\text { classmates }\end{array}$ & 19 & 7,7 & 23 & 9,3 & 65 & 26,2 & 36 & 14,5 & 27 & 10,9 & 3,17 \\
\hline
\end{tabular}

When Table 5 is examined, it is seen that the participants mostly watch videos about subject knowledge $(\overline{\mathrm{x}}=3,58)$ in school. In in-school social media behaviors, it is seen that the participants show the behaviors of sharing learning resources with their classmates $(\bar{x}=3,4)$ and sharing information with their classmates on school-related issues $(\bar{x}=3.27)$. While the participants exhibited at least the behavior of preparing posters, digital art, or graphics $(\bar{x}=2.23)$, they also attributed the behaviors of creating online videos, music, and photos $(\overline{\mathrm{x}}=2.57)$ and writing / article writing $(\overline{\mathrm{x}}=2.72)$ to others. stated that they did less than in the sub-headings of in-school social media behaviors, the participants list consuming behaviors $(\overline{\mathrm{x}}=3.33)$, sharing behaviors $(\overline{\mathrm{x}}=3.15)$, and creating behaviors $(\overline{\mathrm{x}}=2.5)$.

\subsection{Findings regarding the differences in the views of university students on social media behaviors in and out of school according to the gender variable}

The independent t-test was used to determine whether there was a significant difference between the views of the students participating in the research on social media behaviors in and out of school, and their genders. The result of whether the views of the students participating in the research on social media behaviors in and out of school differ according to the gender variable is given in Table 6.

Table 6. T-test results of university students' opinions on social media behaviors in and out of school by gender

\begin{tabular}{|c|c|c|c|c|c|c|c|}
\hline Out & Gender & $\mathbf{N}$ & $\overline{\mathbf{x}}$ & SS & sd & $\mathbf{t}$ & $\mathbf{p}$ \\
\hline & Male & 98 & 2,51 & ,756 & \multirow[b]{2}{*}{132} & \multirow[b]{2}{*}{0,124} & \multirow[b]{2}{*}{.902} \\
\hline & Female & 72 & 2,53 & ,945 & & & \\
\hline \multirow{3}{*}{$\begin{array}{c}\text { In- } \\
\text { school }\end{array}$} & Gender & $\mathbf{N}$ & $\overline{\mathbf{x}}$ & SS & sd & $t$ & p \\
\hline & Male & 98 & 2,93 & ,937 & \multirow{2}{*}{168} & \multirow{2}{*}{455} & \multirow{2}{*}{. 147} \\
\hline & Female & 72 & 3,12 & ,719 & & & \\
\hline
\end{tabular}

According to Table 6 , the arithmetic averages of the total scores of female students $(\overline{\mathrm{x}}=2.53)$ and male students $(\overline{\mathrm{x}}=2.51)$ of the students participating in the research on out-of-school social media behaviors are close to each other, while the inschool averages of female students $(\overline{\mathrm{x}}=2.51) .=3.12)$ than male students $(\overline{\mathrm{x}}=2.93)$ arithmetic mean was found to be higher. The relationship between students' in-school and out-of-school social media behaviors and gender was examined and no statistically significant difference was found [sig. $p>$.05]. Based on these data, it can be said that the gender factor is not important in students' views on internet addiction.

\subsection{Findings regarding the differences in the views of university students on social media behaviors in and out of school according to age variable}

It was investigated whether there was a significant difference between the opinions of the students participating in the study on social media behaviors in and out of school and the age variable. The relationship between the opinions of university students and the age variable was determined by one-way analysis of variance (ANOVA). The result of whether the views of the students participating in the research on social media behaviors in and out of school differ according to the age variable is given in Table 7 .

Table 7. One-way analysis of variance (ANOVA) results of university students' views on social media behaviors in and out of school by age

\begin{tabular}{c|c|c|c|c|c}
\hline Out of & Age Gender & $\mathbf{N}$ & $\overline{\mathbf{x}}$ & $\mathbf{S}$ & \\
\hline \multicolumn{6}{c}{130}
\end{tabular}




\begin{tabular}{c|c|c|c|c|c}
\hline School & & & & & \\
\hline & $18-20$ & 45 & 2,24 &, 657 & \\
\hline & $21-23$ & 62 & 2,46 &, 748 & \\
\hline & $24-26$ & 33 & 2,74 &, 915 & \\
\hline Age Gender & 27 and above & 30 & 2,83 & 1,02 & \\
\hline & $\begin{array}{c}\text { Source of } \\
\text { Variance }\end{array}$ & $\mathbf{K T}$ & $\mathbf{s d}$ & $\mathbf{F}$ & $\mathbf{P}$ \\
\hline & $\begin{array}{c}\text { Between } \\
\text { groups }\end{array}$ & 8,428 & 3 & 4,221 &, 00 \\
\hline & Within groups & 110,486 & 166 & & \\
\hline & Total & 118,914 & 169 & & \\
\hline In School & Age Gender & $\mathbf{N}$ & $\overline{\mathbf{x}}$ & $\mathbf{S}$ & \\
\hline & $18-20$ & 45 & 2,98 &, 879 & \\
\hline & $21-23$ & 62 & 2,89 &, 879 & \\
\hline & $24-26$ & 33 & 3,07 &, 680 & \\
\hline Age Gender & 27 and above & 30 & 3,26 &, 918 & $\mathbf{S}$ \\
& $\begin{array}{c}\text { Source of } \\
\text { Variance }\end{array}$ & $\mathbf{K T}$ & $\mathbf{s d}$ & $\mathbf{F}$ & $\mathbf{P}$ \\
\hline & $\begin{array}{c}\text { Between } \\
\text { groups }\end{array}$ & 2,965 & 3 & 1,361 &, 25 \\
& Within groups & 120,509 & 166 & & \\
\hline & Total & 123,473 & 169 & & \\
\hline & & & &
\end{tabular}

When Table 7 is examined, the mean scores of the university students' views on social media behaviors in and out of school did not show a significant difference according to age [ $p>, 05]$.

\section{Conclusions and Recommendations}

In this research, the views of students studying at the university on social media behaviors in and out of school were determined. In addition to the factors of consumption, communication, creation, sharing on the in-school and out-ofschool social media behaviors of university students, the effects of gender status and the age of the students according to these views were examined and some results were reached. When the studies are examined, it is possible to find many studies on social media behaviors. Especially in recent years, there have been studies on social media behaviors, attitudes, and addictions with university students. No study has been found in the literature that includes investigating social media behaviors in and out of school with different factors. Therefore, it is thought that this study is important in order to shed light on the field. In the answers given by the students who are studying at the university, it is seen that the most agreed propositions are listening to music or watching TV series and movies outside of school, reading the new posts of friends and conveying fun information. It can be stated that university students exhibit social media behaviors for entertainment purposes outside of school. In addition, in school social media behaviors, it is seen that university students have a high rate of watching videos about subject information, sharing learning resources with classmates, and sharing information with classmates on schoolrelated issues. It can be said that the reasons such as the realization of learning environments with distance education due to the Covid 19 pandemic, and current innovations in educational technologies have shaped student behaviors in school more. It can be said that students generally increase their social media use both inside and outside of school. It can be seen that similar results have been obtained in studies in the literature on the subject (Kuss, Griffiths and Binder 2013; Shubnikova, Khuziakhmetov and Khanolainen 2017; Gholamian, Shahnazi and Hassanzadeh 2017). In terms of social media behaviors, e-ISSN: 2148-2683 university students stated that they exhibit less behaviors such as making or rearranging computer and video games outside of school, rearranging the work of others, and creating digital art content in virtual social worlds. In this sense, it can be stated that the participants are less engaged in creating and designing a new material. It is stated that the participants show low rates of preparing posters, digital art or graphics, creating online videos, music and photographs, and writing articles/articles in school. These statements confirm that the participants' in-school and out-of-school behaviors are similar. It can be stated that the participants are not active in creating a new work inside and outside the school. It can also be stated that in recent years, university students have moved away from developing content and materials, as they have more rapid access to information. In the research, it is seen that the participation in the consumption behavior is high in both out-of-school and in-school environments as the subtitles of the behaviors realized by the participants. In this sense, it can be stated that university students are a generation that consumes in the social media environment rather than a generation that produces. In addition, among the behaviors, the creation behavior was the least participation in both environments. This confirms the previous inference. As a result of the research, the views of university students on social media behaviors did not show a significant difference according to age ranges. Based on the findings, it can be said that the age difference of university students is not an important factor in social media behaviors. In the study conducted by Aslan and Yazıcı (2016), internet addiction and related socio-demographic factors did not show a significant difference according to the age variable. In this sense, it is similar to the study carried out. With this research, the views of university students on social media behaviors in and out of school were examined. It was determined that university students' views on social media behaviors did not differ significantly when age and gender variables were taken into account. In future studies, researchers can compare their own samples with the findings from this study. Researchers may be advised to conduct studies on internet addiction by considering different variables. In their future studies, researchers can conduct new research on social media addiction with participants with different demographic characteristics and contribute to the field.

\section{References}

Aslan, E, and Yazıcı, A. 2016. Üniversite Öğrencilerinde İnternet Bağımlılı̆̆1 ve İlişkili Sosyodemografik Faktörler. Turkish Journal of Clinical Psychiatry 19: 109-117.

Aydın, İrem Erdem. 2016. Üniversite Öğrencilerinin Sosyal Medya Kullanımları Üzerine Bir Araştırma: Anadolu Üniversitesi Örneği. The Journal of Selcuk University Social Sciences Institute 35: 373-386.

Barutçu, Süleyman., Tomaş, Melda. Sürdürülebilir Sosyal Medya Pazarlaması ve Etkinliğinin Ölçülmesi. IUYD’2013 4:5-23.

Başol, Gülşah. 2008. Bilimsel Araştırma Süreci ve Yöntem. Bilimsel Araştırma Yöntemleri. Istanbul: Lisans Publication. pp. 113-143.

Baz, Fatih Çağatay. 2018. Sosyal Medya Bağımlılığı: Üniversite Öğrencileri Üzerine Çalışma. International Journal of Society Researches 8(9): 278-295.

Büyüköztürk, Şener. 2012. Örnekleme yöntemleri. Available online: 
content/uploads/2012/03/BAY-Final-Konulari.pdf (accessed on 22 November 2021)

Dikbaş Torun, Emel. 2019. Sosyal Medya Davranışları Ölçeklerinin Türkçe Formunun Geliștirilmesi: Geçerlik ve Güvenirlik Çalışması. Akdeniz İletişim Dergisi 32:217-234.

Gholamian, B., Shahnazi, H., and Hassanzadeh, A. 2017. The Prevalence of Internet Addiction and its Association with Depression, Anxiety, and Stress, among High-School Students. International Journal of Pediatrics 5(4): 47634770.

Greenhow, Christine. 2011. Youth, Learning, and Social Media. J. Educational Computing Research 45: 139-146.

Ince, Mustafa., and Koçak, Mevlüt Can. 2017. Üniversite Öğrencilerinin Sosyal Medya Kullanım Alışkanlıkları: Necmettin Erbakan Üniversitesi Örneği. The Journal of Karabuk University Social Sciences Institute 7: 736-749.

Karasar, Niyazi. 2009. Bilimsel Araştırma Yöntemi (19. Press). Ankara: Nobel Publication.

Keating, Avril., and Melis, Gabriella. 2017. Social Media and Youth Political Engagement: Preaching to the Converted or Providing a New Voice for Youth? The British Journal of Politics and International Relations 19: 877-894.

Komito, Lee. 2011. Social Media and Migration: Virtual Community 2.0. Journal of the American Society for Information Science and Technology 62: 1075-1086.

Özdemir, Zafer. 2019. Üniversite Öğrencilerinde Sosyal Medya Bağımlılığı. Beykoz Akademi Dergisi 7: 91-105.

Öztürk, Mehmet Fatih., Talas, Mustafa. 2015. Interaction of Social Media and Education. Journal of World of Turks. 7: 101-120.

Patton, Desmond, Upton., Hong, Jun Sung., Ranney, Megan., Patel, Sadiq., Kelley, Caitlin., Eschmann, Rob., and Washington, Tyreasa. Social Media as a Vector for Youth Violence: A Review of the Literature. Computers in Human Behavior 35: 548-553.

Power, Daniel J., and Phillips-Wren, Glorai. 2011. Impact of Social Media and Web 2.0 on Decision-Making. Journal of Decision Systems 20: 249-261.

Rice, Eric., and Barman-Adhikari, Anamika. 2014. Internet and Social Media Use as Resource Among Homeless Youth. Journal of Computer-Mediated Communication 19: 232247.

Sandoval-Almazan, Rodrigo., and Gil-Garcia, J Ramon. 2014. Towards Cyberactivism 2.0? Understanding the Use of Social Media and Other Information Technologies for Political Activism and Social Movements. Government Information Quarterly. 31: 365-378.

Sfetcu, Nicolae. 2017. Web 2.0 Social Media Social Networks. Multimedia Publishing.

Shabir, Ghulam., Hameed, Y. M. Y., Safdar, Ghulam., and Gilani, S. M. F. S. 2014. The Impact of Social Media on Youth: A Case Study of Bahawalpur City. Asian Journal of Social Sciences \& Humanities 4: 132-151.

Shubnikova, E. G., Khuziakhmetov, A. N. and Khanolainen, D. P. 2017. Internet-Addiction of Adolescents: Diagnostic Problems and Pedagogical Prevention in the Educational Environment. EURASIA Journal of Mathematics Science and Technology Education 13(8): 5261-5271.

Thackeray, Rosemary., Neiger, Brad L., Hanson, Carl L., McKenzie, James F. 2008. Enhancing Promotional Strategies Within Social Marketing Programs: Use of Web 2.0 Social Media. Social Marketing and Health Communication 9: 338-343.

Tutgun-Ünal, Aylin., Deniz, Levent. 2020. Social Media Usage Levels and Preferences of Social Media Generations. International Journal of Society Researches 15: 1289-1319.
Uluç, Güliz., and Yarcı, Ayşegül. 2017. Culture of Social Media. The Journal of Dumlupunar University Social Sciences Institute 52: 88-102.

Yusop, Farrah Dina., and Sumari, Melati. 2013. The Use of Social Media Technologies among Malaysian Youth. 13th International Educational Technology Conference. 12041209. 